\title{
Size and profitability in co- operative banking: a picture from inside a Portuguese institution
}

\author{
Sérgio Lagoa and Licínio Prata Pina
}

\section{ABSTRACT}

The European co-operative banks play an important role in promoting savings and in financing small and medium enterprises. Their distinctive characteristics have allowed them to get through the Subprime crisis with remarkable resilience. Nevertheless, co-operative banks operate in a very competitive market, where they are constantly under pressure to improve their position. Increasing the size of local co-operative banks is often the strategy used to deal with this pressure. Based on data from a Portuguese co-operative banking group for 2009-11, we assess the impact of size on assets profitability, and conduct a disaggregated analysis of the ratios affecting it. Results indicate that size has an insignificant effect on profitability after controlling for the time-invariant characteristics of each local bank (i.e. caixa). This suggests that the initial higher profitability identified in small and larger caixas vis-à-vis that of medium-size caixas was explained by their specific time-invariant features. However our evidence suggests that size has an indirect effect on return through credit risk: larger caixas have better credit risk management.

KEYWORDS: Banks, co-operatives, profitability, Crédito Agrícola, mergers.

ECONLIT DESCRIPTORS: D240, G210, M100, P130.

Reference: LAGOA, S. \& PINA, L.P. (2015): "Size and profitability in co-operative banking: a picture from inside a Portuguese institution", CIRIEC-España, Revista de Economía Pública, Social y Cooperativa, 83, 201-234.

Correspondence: Corresponding author: Sergio Lagoa, e-mail: sergio.lagoa@iscte.pt, Instituto Universitário de Lisboa (ISCTE-IUL), University Institute of Lisbon, Avenida das Forças Armadas, 1649-026 Lisboa, Portugal. tel: +35 121 3903436, fax: +35 121 7903933; Licínio Prata Pina, Crédito Agrícola, Rua Castilho no. 233, 1099-004 Lisboa, Lisbon, Portugal. 


\section{Tamaño y rentabilidad en la banca cooperativa: una perspectiva desde las entrañas de una entidad portuguesa}

RESUMEN: Los bancos cooperativos de Europa desempeñan una función importante en el fomento del ahorro y la financiación de la pequeña y mediana empresa. Sus características particulares los han dotado de una resistencia extraordinaria para superar la crisis del crédito hipotecario de alto riesgo ("subprime"). No obstante, operan en un mercado muy competitivo en el que están constantemente bajo presión para que mejoren su posición. Con frecuencia, la estrategia adoptada para hacer frente a esta presión es la de incrementar el tamaño del banco cooperativo local. Basándonos en datos de un grupo bancario cooperativo portugués relativos al período 2009-2011, hemos evaluado el efecto que el tamaño de la entidad tiene sobre la rentabilidad de los activos y hemos realizado un análisis desagregado de los coeficientes que la afectan. Nuestros resultados indican que tras analizar en cada entidad de crédito local (es decir, cada caixa) aquellas características que no varían a lo largo del tiempo, la influencia del tamaño de la misma sobre la rentabilidad es insignificante. Ello indica que la mayor rentabilidad identificada inicialmente en las pequeñas y grandes caixas, frente a aquellas de tamaño mediano, se explicaría por las características específicas de cada una que permanecen invariables con el tiempo. Sin embargo, existen indicios de que el tamaño incide sobre la rentabilidad de forma indirecta, a través del riesgo crediticio, que las caixas grandes gestionan de forma más adecuada.

PALABRAS CLAVE: Bancos, cooperativas, rentabilidad, Crédito Agrícola, fusiones.

\section{Taille et rentabilité des banques coopératives : vue de l'intérieur d'une institution portugaise}

RÉSUMÉ : Les banques coopératives européennes jouent un rôle important dans la promotion de l'épargne et dans le financement des petites et moyennes entreprises. Leurs caractéristiques distinctes leur ont permis de traverser la crise des prêts hypothécaires à risque avec une remarquable ténacité. Cependant, elles évoluent dans un marché très compétitif, où elles sont sous pression constante pour améliorer leur positionnement. La stratégie adoptée en réponse à cette pression est souvent l'augmentation de la taille des banques coopératives locales. En nous basant sur les données de 2009-2011 d'un groupe bancaire coopératif, nous évaluons l'impact de la taille de l'institution sur la rentabilité des actifs et réalisons une analyse détaillée des ratios s'y rapportant. Les résultats indiquent que l'incidence de la taille sur la rentabilité est négligeable après prise en compte des caractéristiques invariables dans le temps de chaque banque locale (ex. caixa). Cela suggère que la rentabilité initiale supérieure identifiée chez les petites et plus grandes caixas comparativement aux moyennes s'explique par des caractéristiques spécifiques invariables dans le temps. Cependant, les preuves réunies suggèrent que la taille a un effet indirect sur la rentabilité au niveau du risque de crédit : les caixas plus importantes ont une meilleure gestion du risque de crédit.

MOTS CLÉ : Banques, coopératives, rentabilité, Crédito Agrícola, fusions. 


\section{1.- Introduction 1}

The co-operative model is a third model of corporate organization that educates and qualifies participants, supports and sustains the generation of wealth, and fosters self-sustainability for social development with less inequality and involving communities. The United Nations recognizes the co-operative business model as an important factor in economic and social development, and declared 2012 as the international year of co-operatives.

Credit co-operatives have a strong local presence and are especially important for promoting savings, financing small and medium enterprises; they therefore contribute to the creation of employment and wealth. The European co-operative banking sector is composed of 4,000 local and regional banks, more than 65,000 branches and employs over 783,000 persons (Guider and Roux, 2009). In the EU15, co-operative banking represented around $14 \%$ of the loans and deposits of the banking industry in 2007 (EACB, 2010).

The majority of local co-operative banks have evolved to national organizations with a diversified offer of financial services as a result of regulatory requirements or to enhance efficiency (Groeneveld, 2014). Some of the largest European co-operative groups in terms of assets are Crédit Agricole, Rabobank, Dz Bank, RZ Bank, Caja Rural, and Op-Pohjola. In Portugal, Crédito Agrícola (CA) is the only co-operative bank and is the focus of our study.

Traditionally, co-operative groups have a pyramidal structure with a central body and several autonomous local banks. In the case of CA, the Caixa Central (CC) is the central body and the caixas are the local banks. CA has no regional bank working as an intermediary between the local caixas and the central bank (i.e. the CC). In general, European co-operative banks (including CA) have internal deposit guarantee funds that serve as a solidarity scheme between local banks.

Other characteristics of European co-operative banking groups are highlighted by Zurdo (2008). Local co-operative banks share the same identity, similar legal status and functions. However, they are not linked through patrimony, but are indirectly connected by an organization that represents them or by independent participations in a central organization or specialized firms. Due to the lack of intercompany capital participations, parent-subsidiary relations, or other forms of corporate control, co-operative groups are not business groups in the traditional sense but work as de facto groups. In some cases, accounts are consolidated and the central structure acts as the supervisory body of local banks. Groups have specialized central structures and companies that complement the offer of products by local banks and allow the group to reach scale economies in specific services.

1.- We thank Mohamed Azzim Gulamhussen for his comments. The usual disclaimer applies. 
However, co-operative banks also differ from each other in various aspects, including the level of integration of the group, size, level of sophistication, governance, and range of activities (Kuijpers, 2011).

In general, the characteristics of co-operative banks are distinct from those of commercial banks as they are essentially democratically controlled by members, customers are also members, their aim is not to maximize profit but to serve customers/members, they have a long-term orientation with moderate risk profile, and the return of capital is modest and stable (Groeneveld and Sjauw-KoenFa, 2009; Groeneveld, 2014). Co-operative banks are more conservative than other banks and take a traditional approach to the banking business, characterized by originate-to-hold, and with a larger capital base. These characteristics together with careful risk management contribute positively to the stability of the national financial systems (Hesse and Cihák, 2007). They are predominantly domestic and retail oriented and closely attached to the local economies. The competitive advantages of European co-operative banks have been client trust, and the low cost of the cooperative capital (Fonteyne, 2007).

Nevertheless, co-operative banks face interconnected internal and external challenges. At the internal level, they cannot allow the capital accumulated across generations to be used for the own interests of the management (Fonteyne, 2007). Moreover, Fonteyne (2007) also emphasizes that democratic governance mechanisms are more difficult to apply in large co-operatives, which creates challenges for collective participation in these banks. Gijselinckx and Develtere (2008) study five large European co-operative financial groups and find no loss of co-operative principles as market pressure increases. On the contrary, these groups have found innovative modes of ensuring the participation of members and use a multi-stakeholder approach while pioneering socially responsible financial services and supporting non-profit ventures.

The co-operative banking model also faces considerable external challenges. There are three strong trends in Australia, USA, and UK (Worthington, 2004), and also in other European countries. Firstly, deregulation eliminated some restrictions on co-operative banks' operations and imposed capital requirements similar to other banks, creating pressure to generate profits to increase capital. Regarding the new Basel III capital regulation, the main challenge for co-operative banks is that regulations takes their specificities into account. The main issue is whether co-operative capital is considered TIER I capital. The higher demands of capital and liquidity brought by Basel III are also an important restriction on banks in general and co-operative banks in particular.

Secondly, there is greater emphasis on the commercial objectives of co-operative banks, with efficiency and financial issues gaining prominence over the maximization of services to members. Cooperative banks are in open competition with commercial banks, suffering pressure to improve their competitive position in the market. Some European co-operative banking groups have even become partially listed and a few have become internationally active (Groeneveld, 2014). 
Finally, there is a trend towards more integration of activities in national organizations in order to centralize strategic and operational functions (Groeneveld, 2014), with M\&A as one of the main tools used to adapt to this trend. In some European co-operative bank groups, a consolidation process has taken place among local banks with geographical proximity in order to increase size and thus competitive capacity (Zurdo, 2008).

Despite the challenges faced, co-operative banks performed better in the financial crisis of 2008 than standard commercial banks, with fewer losses and no bankruptcy registered (EACB, 2010). Groeneveld (2014) shows that although downturns in general led to a deterioration in the performance of co-operative banking groups in Europe, this decline was smaller than in other banking groups. He also finds that co-operative banking groups have a different behaviour in times of prosperity.

The research question raised in this paper is: what is the relationship between the size of caixas and their profitability in CA? A priori, there are arguments in favour of both large and small banks and this is the reason for the empirical research conducted herein. For instance, while scale economies justify large financial institutions, a focus strategy based on a close relationship with clients validates the existence of small institutions. Moreover, in a co-operative institution, small organizations favour the participation of members in corporate governance.

In co-operative banking literature, various methods have been used to analyse this topic, such as stochastic frontiers or frontiers obtained with Data Envelopment Analysis to estimate technical, allocative and total efficiency (Worthington, 2009). In this work, we take a simplified approach in which we explain the return on assets using a regression with a random error with only one component. Not only is this a more innovative approach in the study of co-operative banks, but it allows a detailed analysis of the sub-elements of the return as the methodology is easy to apply and interpret.

This paper has three features not commonly found in the literature that give it added value. Firstly, our focus is on profit efficiency whereas most other studies address cost efficiency. Secondly, in addition to studying banks' aggregate profitability, we assess the impact of size in the sub-components of profitability. Thirdly, we answer the research question by using information at the level of the local banks comprising the CA bank. The use of intra-firm (i.e. intra-group) level data is unusual in the literature (Worthington, 2009).

The remainder of the paper is organized as follows. Section 2 provides a characterization of CA. Section 3 reviews the literature linking bank size with efficiency and profitability, before reflecting on the specific case of the caixas. Section 4 presents the methodology and data used to study the relationship between size and profitability in the caixas, while Section 5 provides the empirical results and discussion. Finally, Section 6 concludes. 


\section{2.- Characterization of the Crédito Agrícola and caixa mergers}

This section addresses the historical evolution of $\mathrm{CA}$, its characterization and current importance in the Portuguese banking system. CA is the only Portuguese co-operative bank and despite a historical connection to agriculture, nowadays it is an almost universal bank. CA is a modern bank with good economic and financial indicators, competing openly in the banking market and offering a wide range of products. It ranks seventh in the Portuguese domestic market, with a market share in 2010 of about $3 \%$ on credit and $5 \%$ on deposits. Nevertheless, its presence is disproportionately large in rural areas, with a market share of over $30 \%$ in some of these areas, but it has a weak presence in urban areas.

Like other European co-operative banks, CA has some characteristics that distinguish it from commercial banks (Barradas et al, 2011). The bank offers proximity banking services, is involved with local communities in promoting local development, especially in rural areas (see also Ferreiro et al, 2012), has an important social responsibility activity and a conservative approach to banking, and its goal is not to maximize profit but to offer quality services to its members and clients.

Turning to strategy and using the Ballarín (1985) definition of strategic behaviour, CA has chosen universal banking (product strategy), incorporating results to increase capital (distribution of value created), and a focus on local and regional banking (geographic strategy).

Besides CC, its central body, CA is composed of 82 local or primary banks (caixas) spread across the country (Table 1) which form a large network of 681 branches, with an above average presence in inland regions (Barradas et al, 2011). The group has one million and two hundred thousand clients, 400 thousand members, and 14 thousand million euros of assets.

The caixas are very heterogeneous due to distinct dimensions and dynamics of local markets and in management. The assets of the largest caixa are 30 times greater than the smallest caixa. The smallest caixa covers only one freguesia (the smallest administrative area in Portugal and smaller than a county), has 6 employees and 14.2 million euros worth of assets. The largest caixa covers 13 freguesias and has 161 workers and 452.5 million of assets.

The CA had no specific regulations from its foundation in 1911 until 1991 when the Decreto-Lei no. 24/91 of 11 January - Regime Jurídico do Crédito Agrícola (RJCAM) - came into effect. This law created the conditions for the formation of the CA financial group. Several changes have since been made to these regulations, namely in 1997, 1999 and 2009 and have successively approximated the $\mathrm{CA}$ to a standard commercial bank in terms of the credit operations it is authorized to make. CA has gone from a bank that could only grant credit to agriculture and related activities to one that can provide all types of credit to members and non-members. 


\subsection{The relationship between the Caixa Central and the caixas}

The CC was created in 1985 and the 1991 law strengthened its power over the caixas and allowed the CC to manage liquidity (apply the surplus financial resources of the caixas and finance them), facilitate payments between caixas, and supervise them.

\section{Table 1. Regional distribution of caixas and branches (2009-11)}

\begin{tabular}{|lcc|}
\hline Distritos & Caixas & Branches \\
\hline Aveiro & 12 & 46 \\
Beja & 6 & 29 \\
Braga & 6 & 33 \\
Bragança & 4 & 25 \\
Castelo Branco & 3 & 21 \\
Coimbra & 8 & 47 \\
Évora & 7 & 35 \\
Faro & 7 & 63 \\
Guarda & 4 & 26 \\
Leiria & 8 & 52 \\
Lisboa & 11 & 56 \\
Portalegre & 7 & 27 \\
Porto & 8 & 49 \\
Santarém & 18 & 40 \\
Setúbal & 3 & 27 \\
Viana do Castelo & 1 & 18 \\
Vila Real & 3 & 26 \\
Viseu & 8 & 44 \\
Autonomous Region of Açores & 6 & 17 \\
\hline Total & - & 681 \\
\hline
\end{tabular}

SOURCE: Data on caixas was obtained from CA and data on branches from Associação Portuguesa de Bancos. The number of caixas includes those outside $C A$ Bank. Please note that the number of caixas does not include the $\mathrm{CC}$, but the number of branches in Lisboa and Porto includes the branches of $\mathrm{CC}$. Also note that some caixas are in more than one distrito, implying that the total number of caixas is more than 82 .

The creation of the CC led to the rapid evolution of $\mathrm{CA}$ (Santos, 2012), namely a significant improvement in terms of technology (with a single computer network connecting all branches and caixas), risk management, employees' qualifications, standardization of procedures and organization, and reduction of the number of caixas. 
The CC also takes the form of a co-operative and is $100 \%$ owned by the caixas, which are in turn owned by their members. The relationship between the caixas and the CC is regulated by the RJCAM. The CC and caixas have separate balance sheets and profit and loss accounts that consolidate to form the accounts of the CA bank. Profits of CC and caixas are almost always used to reinforce their respective capital.

Caixas are independent banking institutions with their own governing bodies. Nevertheless, they are not entirely independent as they must comply with a number of CC rules and procedures. Firstly, caixas must lend their excess liquidity to the $\mathrm{CC}$ or invest it in Government bonds. Caixas with a deficit of liquidity borrow money from the CC and not from the Interbank Money Market (IMM). CC consolidates the liquidity positions of all caixas and can also access the IMM. Secondly, caixas must also follow CC's management rules regarding interest rates on credit and deposits, commercial policy, internal audit, hiring policy and human resource management in general. Thirdly, caixas are not allowed to open branches outside the geographical area established in their statutes. They can however exercise commercial activity outside their geographical area although this is not usual. Fourthly, caixas are supervised by the $\mathrm{CC}$ and the Banco de Portugal - Bank of Portugal - (monetary and supervisory authority that belongs to the Eurosystem). The regulation of capital by the Supervisory Authority is made in consolidated terms at the CA bank level, i.e., the Banco de Portugal does not oblige individual caixas to have a minimum TIER I capital ratio, currently of $8 \%$ ( $7 \%+$ buffer). The same is valid for liquidity ratios. Notice that the legislation produced by the Banco de Portugal has imposed the same supervisory conditions and obligations on the CA in consolidated terms as on other banks.

Despite the fact that the capital regulation of Banco de Portugal is done in consolidated terms, the CC imposes several minimum ratios on the caixas, namely minimum capital and liquidity ratios, and a maximum for the transformation ratio $(85 \%)$. All caixas should have a minimum capital of 5 million euros from 1 January 2015.

However, Banco de Portugal imposes rules directly on the caixas; these include the segregation of the risk control area and the commercial area, the obligation of semi-annual report on various risks, reports on reverse stress testing, concentration risk, adequacy of internal capital in general and for large risks in particular (large risks cannot exceed $25 \%$ of the capital) and on market discipline. Regulatory obligations of individual caixas are differentiated according to their asset size. Naturally, the Supervisory Authority can ask caixas directly for other information when deemed necessary.

CC also conducts risk audits on the caixas, and can remove the board of directors and appoint new interim directors when there is any illicit or imprudent management or conflicts in the governing bodies. The management and other governing bodies of the caixas must obtain prior approval from the $\mathrm{CC}$ and then from the Supervisory Authority. 
The Guarantee Fund of the Crédito Agrícola, formed in 1987 and redefined in 1998 and 2008, is another institutional element that unifies the caixas. The Guarantee Fund includes the CC and associated caixas. Since it is not mandatory to join the Guarantee Fund, there are 5 caixas outside this system of mutual accountability and solidarity. The Fund's main goal is to guarantee the deposits in the caixas and CC and take any action deemed necessary to ensure their liquidity and solvency. Several caixas have already benefited from subordinated loans from the Guarantee Fund totalling 240 million euros, usually associated with mergers of caixas with negative equity. In all, 44 caixas have already received support from the Guarantee Fund under contracts of financial assistance, and eight caixas still had an active contract in 2011 involving subordinated loans from the Guarantee Fund to strengthen their capital base.

The hierarchical structure of the cooperative is formed by the umbrella organization, the CA financial group, at the top which includes the CA bank, specialized firms (CA-Non-life Insurances, CA - Life insurances, Investment funds of financial assets and real estate, and CA Management of mutual funds), and other central units that provide support to the group, especially the CA Computer Services and the CA Services. The provision of more complex products (insurance and investment funds, for example), transactions in the financial markets, and international transactions are the responsibility of the $\mathrm{CC}$ or other $\mathrm{CA}$ group central units.

The existence of the $\mathrm{CC}$ and other central firms permits the sharing of operational, technological, and commercial structures, which allows the caixas (especially the small ones) to reduce costs by exploring scale economies and have a larger offer of financial products. The services offered to all caixas by the central entities (e.g., marketing, information systems and technologies, and assets management) avoid the duplication of costs and facilitate the integrated functioning of services. The Grupo Caja Rural also brings the same type of advantages for the small Cajas Rurales operating in the Spanish market (Duval, 2010).

\subsection{The $\mathrm{CA}$ and the recent financial crises: strengths and weaknesses}

During CA's long history, it has experienced many different macroeconomic environments. The Subprime crisis of 2008 and the Euro sovereign debt crisis of 2010 led to a deep recession in the Portuguese economy and ultimately the request for financial assistance from the Troika (ECB, IMF and European Commission). In this context, the economic and financial indicators presented by $\mathrm{CA}$ are among the best in the Portuguese banking system. The CA was the only institution of the main banking groups that already satisfied the criteria defined by Troika in 2010: Core Tier 1 should be 10\% in 2012 and the credit to deposit ratio should be lower than 120\% in 2014. With the onset of the crisis of confidence and liquidity in late 2008, the low transformation ratio proved an unquestionable strength of CA bank (Coelho, 2011). Moreover, CA was the only large banking institution that managed to increase its profit in 2011; the earnings of the others banks were down and some even presented negative results in the domestic activity. 
Looking at the performance of the caixas, the average ROA declined in 2010 but recovered in 2011 (Table 2). The number of caixas with a negative ROA increased in 2010 to seven before going down to four in 2011. Overall, caixas have shown good resilience during the financial and economic crisis.

\section{Table 2. Performance of the caixas}

\begin{tabular}{|l|ccc|}
\hline & 2009 & 2010 & 2011 \\
\hline Average ROA (1) & 0.4071 & 0.3488 & 0.5325 \\
& $(0.5894)$ & $(0.5636)$ & $(0.3998)$ \\
\hline Number of caixas with negative ROA & 4 & 7 & 4 \\
\hline
\end{tabular}

SOURCE: Authors' calculations. Note: (1) - standard deviation in parenthesis.

In CA, caixas do not close due to bankruptcy but cease to exist as an independent organization and are integrated in other neighbouring caixas. Nevertheless, no caixa ceased its activity between 2009 and 2011; indeed, in CA's entire history only three caixas ceased to exist: in 1998 and 2003. In general, a merger takes place before problems of insolvency arise in a caixa.

It is the practice of "proximity banking" that has ensured the survival of CA and enabled it to face the financial crisis with an unparalleled resilience. By proximity banking, we understand a practice of banking with decision centers close to clients, a large network of branches, cooperation with local communities in the promotion of economic development, provision of quality services with a long run perspective, and the development of a relationship of trust between the bank and clients.

In the difficult economic environment after 2008, one of the CA's main weaknesses was its high operating costs. According to the Portuguese Banking Association data, in 2008-10 the cost-to-income ratio of $C A$ was larger than the sector average: $60.7 \%$ and $54.1 \%$, respectively. Another weakness of the caixas is that they are particularly exposed to downturns in local economies due to their strong local market presence. These weaknesses are offset by geographical proximity to clients, deep knowledge of local economic realities, brand reputation, and customer loyalty. In addition, the continuous rethinking of the business strategy has also played a key role in the CA performance, namely the use of mergers and alliances between caixas.

\subsection{Caixa mergers}

In our opinion, several factors have led to the merger of caixas in the last years. Firstly, mergers were used up to 2002 to improve the profitability and capitalization of poorly run caixas. The caixas in financial difficulties received financial support from the Guarantee Fund of the CA bank and were forced to merge with other geographically contiguous caixas with a sound financial situation. 
Secondly, the existence of scale economies, investment in technology and the need for qualified personnel justifies the creation of larger units in order to increase their competitive capacity (Cabo, 2003; Cabo and Rebelo, 2005).

Thirdly, after 2002 new regulations demanded stronger compliance and risk control structures, creating a pressure to increase the size of caixas as a relatively large minimum size is necessary to comply with regulatory demands. It should also be noted that after the Subprime crisis the Portuguese supervisory authority issued a number of new rules and created novel supervision structures, including behavioural supervision. For example, the Banco de Portugal Aviso no. 5 of 2008 obliged semiannual reporting on several banking risks and required the segregation of duties between those who control risk and the commercial area. This new position of the supervisory entity has forced banks to make large investments and increased costs.

The concentration risk from the perspective of credit, liquidity, market and operational risks have also been subject to greater scrutiny by the regulator (Banco de Portugal Instrução no. 5 of 2011). Concentration risk is linked particularly to single-name exposures, exposure to sectors of activity, concentration of revenues in specific products, and portfolio concentration in regions of the country. The merger of caixas constitutes a good tool to mitigate concentration and overall risks (Batista, 2010).

Additionally, a caixa needs to be a considerable size to implement the standard organizational chart advocated by the CC, namely due to the demands regarding risk functions i.e. an Audit Board, Board of credit, internal audit functions, internal control functions, risk management functions, compliance functions, a credit risk department and a sub-department of accounting and reporting. In our opinion, a caixa can only comply with this chart if it has a technical staff of over 30 people in central structures. It follows that a caixa must be large enough to generate sufficient cash flow in order to adopt this structure.

Although some small caixas have remained independent due to support in the form of internal auditing, risk analysis and compliance services from the $\mathrm{CA}$, this relationship cannot last much longer and these caixas should merge with others to gain the minimum scale for these functions. Moreover, in 2015 , the minimum capital requirement will be raised to 5 million euros by resolution of the CC, which will imply at least three more mergers, according to $\mathrm{CA}$ information.

The above mentioned factors explain the recent wave of mergers. From a historical maximum of 220 caixas, the CC has promoted a number of mergers since 1986. The number of caixas fell from 126 in 2003 to 82 in 2012 (Table 3). Mergers between small units have reduced the asymmetries in the universe of caixas and increased the average size of caixas from 61.5 million euros of assets in 2002 to 132.3 million in 2010. 
Table 3. Evolution of the number of mergers

\begin{tabular}{|l|ccccccccccc|}
\hline Year & 02 & 03 & 04 & 05 & 06 & 07 & 08 & 09 & 10 & 11 & 12 \\
\hline Caixas at the end of the year & 126 & 120 & 118 & 111 & 105 & 100 & 92 & 88 & 85 & 83 & 82 \\
No. mergers & & 6 & 2 & 7 & 6 & 5 & 8 & 4 & 3 & 2 & 1 \\
\hline
\end{tabular}

SOURCE: CA Consult (2011).

Acquired Caixas are generally poorly managed, have low capital, or are not large enough to comply with the new Banco de Portugal regulations. Cabo (2005) shows that the acquiring caixas are larger, more profitable and have better credit management, while the acquired caixas are smaller, and have both credit management and leverage problems. Lima (2012) uses a model to predict the probability of failure and concludes that smaller caixas, with more bad loans in total credit, and larger staff costs to operating income have a higher probability of failure (i.e. merger with another wealthier caixa).

Some argue that mergers have been an important tool to reorganize and foster the growth of $\mathrm{CA}$ through the creation of larger and more competitive units, with better technical structures, financially more stable, and with human and materials resources that mitigate risks and potentiate business. Batista (2010) indicates that this was the case with the caixa of the Litoral Alentejano. Nonetheless, Cabo and Rebelo (2005) did not find a positive effect of mergers in cost efficiency, credit management and solvency ratios of caixas.

In the mutual banking literature, other studies also find an insignificant or negative effect of mergers on efficiency (Brown, Brown and O'Connor, 1999; Ralston et al, 2001). Ralston et al (2001) find that mergers among credit unions have a positive effect on efficiency in some of the acquirer and target institutions, but a negative effect on others; and the gain is not larger than what can be achieved through internal growth. But Worthington (2001) discovers a positive effect of mergers on technical and scale efficiencies among Australian CUs. In the same universe of institutions, Worthington (2004) concludes that M\&A may increase the efficiency of the industry because acquiring CUs are larger, with larger earnings and greater managerial skills. 


\section{3.- Literature review and justifications for larger caixas}

\subsection{General arguments}

We start this section by reviewing the arguments on the effect of size on banks' performance. According to the neoclassical approach, the goal of firms is to maximize profit by achieving maximum efficiency in the use of resources and taking advantage of market conditions to increase revenues. Firms not only aim to produce at low costs, but above all to achieve the maximum sustainable profitability.

Larger banks may be more efficient or profitable for several reasons. Larger financial institutions may produce at lower unitary costs by taking advantage of scale and scope economies and greater management efficiency. Scale economies are clearly visible in information systems, which can accommodate very different levels of production with the same fixed cost. Boyd and Runkle (1993) notes the reduction in the cost of gathering and processing information as one of the main advantages of large banks. Scale economies may also be obtained by serving large clients and practicing syndicated banking. Regarding scope economies, the most evident example occurs in the use of information systems to cross-sell products. Larger banks also benefit more from technical progress (Altunbas, et al, 2001).

Scale economies have been found extensively in European banking, notably for smaller banks, and also in co-operative banks (see Molyneux et al., 1996, Chapter 6, for a review of the literature). The evidence on scope economies is less clear, with only a small number of studies finding them in European banks, and mainly for large banks (Altunbas and Molyneaux, 1996). However, evidence of scope economies was also found in German co-operative savings banks (Lang and Welzel, 1996).

Revenue efficiency may increase with size due to growing market power or because some clients prefer the services of larger institutions (Berger et al., 2001). The exercise of market power is facilitated because the banking industry has entry barriers, especially scale and scope economies. Larger banks may also be more diversified and thus obtain more stable revenues. However, small Spanish Cajas Rurales benefit in terms of interest margins from operating in local markets that are more isolated and less exposed to competition from banks and Cajas de Ahorros (Duval, 2010).

Another justification to increase size in banking is that it improves the ability to absorb risks (Jones, 1988). In theory the larger the credit portfolio of a bank, the greater the risk diversification is in terms of sectors and individual clients, and the less dependent it becomes on fluctuations in the local economy. Indeed, Posiouras and Kosmidou (2007) found that larger banks are more profitable because their products and loans are more diversified. Larger banks therefore have less risk, which means they can collect funds at a lower cost (Worthington, 1999). 
Even though size may bring advantages to banks, an increase beyond a certain threshold may be counterproductive as it leads to greater bureaucracy and other scale inefficiencies (Berger et al., 1987; Athanasoglou et al, 2008). In line with this argument, McKillop et al. (2002) found decreasing returns to scale in large UK credit unions that had made extensive investments in buildings, staff and technology from which they could not obtain a large return due to limitations imposed by their credit union status on the provision of services.

Some banks may increase profitability by either increasing product differentiation or opting for a niche strategy rather than changing size (Porter, 1980). Greater differentiation usually implies larger costs but may lead to increased overall profitability. This is also true of a niche strategy, in which serving a specific clientele may prove profitable. Naturally, the quality of management is always an important determinant of profitability regardless of the strategy adopted and size.

Given the diversity of strategies that can be followed, empirical studies on mutual/co-operative financial institutions are not expected to detect a clear positive relation between size and efficiency measured. Some works using frontier methods find a negative effect of size on efficiency (Field, 1990; Drake and Weyman-Jones; Esho, 2001) while others point to the importance of scale for better efficiency scores (Worthington, 1999; and McKillop et al, 2002). However, Worthington (1999) suggests that $X$-inefficiencies (capacity of the management to reduce costs and increase revenues) are more important than the incorrect size of operations.

In a study of the efficiency of credit co-operatives in Spain (mainly cajas rurales) with Data Envelopment Analysis, Ureña and Úbeda (2008) find that the larger co-operatives have greater technical efficiency. However, the smaller institutions are more attached to the co-operative principles (preference for members, more personalized service to clients, and orientation towards the social impact).

Other literature explores the relationship between profitability and size. Micco et al. (2007) and Athanasoglou et al. (2008) find that profitability is not affected by bank size, whereas Pasiouras and Kosmidou (2007) find a negative relationship between bank size and profitability. Dietrich and Wanzenried (2011) shows that small and large Swiss banks were more profitable than medium-sized banks before the 2007-09 crisis.

Some authors link size of banks and other measures of performance. Goddard et al (2008) explains the growth of assets of US credit unions and concludes that individual credit union effects e.g. decisions on staffing and product portfolio, explain heterogeneous performance more than sector effects e.g. geography or common bond.

Palacio (2003)'s survey of the cajas rurales of the Comunidad Valenciana in Spain do not find a relationship between the size of the caixa and its implantation in the local market. This and the differentiation strategy based on a close contact with clients, together with cooperation strategies among 
cajas lead Palacio to argue that the current size of cajas may be a valid strategy to survive the transformations in the Spanish market.

Analysing operational efficiency ratios and return of Spanish Cajas Rurales, Duval (2010) finds the need to reduce operational costs through the consolidation of operational structures. This should be done by internal growth and M\&A, and by other ways of exploring scale economies such as concentration of back-office operations in shared centres, and greater use of the electronic channel.

The strategy of mergers and absorption among Spanish cajas rurales has already been followed for some time in order to increase size and thus improve efficiency in light of the changes in the banking market (Palacio, 2003). Simultaneously, in the 1999-2008 period cajas rurales had already followed an expansion process to outside the territory (provincia) they had started and were strongly implanted (Urenã and García, 2010).

Despite these evolutions and even though the co-operative banks in Spain had no solvency problems during the recent financial crisis (2008-11), regulators and sector representatives agree that some of them are still too small (García, 2011). As a result, the merging of institutions and the creation of several co-operative groups has intensified during and since the crisis.

\subsection{The specific reality of caixas}

Generally speaking, it is our opinion that caixas are driven to become larger by the same factors as standard commercial banks (Table 4). It can be argued that some of these factors are even more important in the caixas than in standard banks because their relatively small size means they are probably more distant from the minimum optimal size. For example, some caixas cannot support the technical structure necessary for a competent and timely response to the growing prudential requirements imposed by the regulator unless they increase in size.

But given their special features, caixas are less affected by shareholder pressure to increase profitability than commercial banks. Co-operative banks either own their own capital as a result of the incorporation of results, or it is owned by their members.

Moreover, the growth of the caixas may lead to a reduction of the personalized relationship with clients and members that is normally present in small institutions. Firstly, the growth of the caixas can distance the decision-making centres from customers. Secondly, if the increase in size of caixas involves the closure of branches, proximity banking may be diminished. Finally, the participation in the corporate activity of the caixas is also impaired when they become large units and members are less involved in co-operative affairs due to increased free-riding. As a result, the Dutch co-operative bank Rabobank uses the formula of considering their local banks "as large as necessary and as small as possible". 


\section{Table 4. Factors affecting bank size}

\begin{tabular}{|lcc|}
\hline & Commercial banks & Caixas \\
\hline Scale economies & + & ++ \\
Scope economies & + & + \\
Prudential requirements & + & ++ \\
Credit risk & + & + \\
Reduction of competition & + & + \\
Proximity banking & - & - \\
Shareholder pressure to increase profit & + & 0 \\
Democratic control & 0 & - \\
\hline
\end{tabular}

Note: +: pressure to increase size, 0 : no effect on size, -: pressure to decrease size.

SOURCE: Authors' formulation.

\section{4.- Methodology and data}

This section sets up the methodology to analyse the relationship between profitability and size in the caixas. The measures of output and input are difficult to select as we need to take into account that banks are multiproduct institutions. We chose to measure efficiency using an aggregate indicator of profitability, the return-on-assets, ROA (profit after taxes/assets). ${ }^{2}$ This financial ratio shows an institution's capacity to generate profits based on its assets and it was chosen because it is a global indicator of performance not affected by the bank's leverage. The disadvantage of using ROA is that the main goal of the caixas is not to maximize return; however, they do need to achieve a sufficient rate of return to guarantee their solvability and growth.

The ROA can be disaggregated using the formula:

$$
R O A=B P / A-O C / A-P / A-D / A-O R / A-T / A
$$

where $B P$ is banking product, $O C$ operational costs, $P$ provisions and impairments, $D$ depreciations, $O R$ other results, $T$ taxes, and $A$ assets.

The banking product is the set of revenues generated by the bank and is the sum of net-interest income and non-interest income. The net-interest income is the difference between interest received

2.- Assets exclude provisions and depreciations. 
and paid. This is the gross profit that the bank has from credit granting activities and investment in bonds after deducting financing costs. Non-interest income gives us the margin achieved with activities other than granting credit, and corresponds to the sum of revenues minus commission costs (from activities on and off the balance sheet such as the selling of insurance and investment funds), profits minus losses from financial operations, and other income minus both other operating costs and other taxes (other than taxes on profit).

The financial margin (FM) -net interest income to assets- can be further analysed by looking at the average credit and deposit rates. Using the assets and liabilities that originate interest (financial assets -FA- and financial liabilities - FL), we have

$$
\mathrm{FM} / \mathrm{FA}=\mathrm{IC} / \mathrm{FA}-(\mathrm{IP} / \mathrm{FL})^{\star}(\mathrm{FL} / \mathrm{FA})
$$

with IC as interest charged and IP as interest paid. The average credit rate is simple IC/FA and the average deposits rate is IP/FL. The average credit rate is determined by interest received from clients, investments in bonds and loans to the CC (which manages caixas' excess liquidity). The average deposit rate depends on the interest paid to clients on their deposits and to the CC on its loans.

Operating costs include labour costs and general administrative costs. Provisions and impairments include the new provisions minus the cancellation of provisions and impairments for losses, namely in the credit portfolio. The ratio of provisions and impairments to assets depends on the quality of credit risk management but also on the guarantees supporting credit and the age of the credit portfolio.

Depreciations of physical and non-physical assets register the economic deterioration of assets. Caixas obtain computers through leasing and this is recorded as a general administrative costs and does not affect depreciations, which essentially include the deterioration of real estate used by the local banks.

Other results include the remaining accounts, namely extraordinary costs and revenues. Taxes include taxes on profits. The item "other results" are not analysed individually given their residual importance. The item "taxes" is also not examined in detail because the efficiency of tax management is not of interest to us.

Our goal is to assess the impact of caixa size on its ROA. We start by applying a univariate analysis where only size explains return and the sub-components of return (see equation (1)). We then introduce more variables that may explain ROA, following a similar approach to that of studies on the determinants of profitability such as Athanasoglou et al. (2008) and Dietrich and Wanzenried (2011). Total assets (in euros) was chosen as the variable to measure bank size. Our analysis includes the 84 caixas operating at the end of 2011 (excluding the CC), and data for the 2009 - 2011 period. ${ }^{3}$ Table A1 includes descriptive statistics of data.

3.- We include three observations, one per each year, for each caixa. Please note that the caixas operating in 2009 and 2010 but that merged with others up to the end of 2011 were not included in the analysis as independent organizations. 


\section{5.- Results and discussion}

\subsection{Univariate analysis}

Starting with the descriptive analysis of the data, the caixas are divided into three groups according to size of assets: less than 150 million euros, from 150 to 350 million and over 350 million. We can observe in Table 5 that CA is dominated by small size caixas: two-thirds of the caixas can be classified as small and only a small proportion is large.

The small caixas perform better than medium and large caixas in all indicators with the exception of operating costs and depreciations (Table 5). The ROA of small caixas is 0.116 p.p higher than that of large caixas. This is explained by the fact they have a bigger financial margin than large caixas $(2.683 \%$ versus $2.443 \%)$, as well as a bigger non-interest margin $(0.811 \%$ versus $0.748 \%)$. Therefore, the banking product to assets ratio in small caixas is higher than in larger caixas.

In contrast, large caixas benefit from economies of scale that allow them to have lower operating costs to assets and fewer depreciations to assets. The medium-sized caixas are the worst for all indicators.

\section{Table 5. Main ratios by size of caixa (2009-11)}

\begin{tabular}{|l|cccc|}
\hline Ratios & $\begin{array}{c}\text { Small size: } \\
<€ 150 \text { Million }\end{array}$ & $\begin{array}{c}\text { Medium size: } \\
€ 150 \text { to 350 Million }\end{array}$ & $\begin{array}{c}\text { Large size } \\
>€ 350 \text { Million }\end{array}$ & $\begin{array}{c}\text { Average of all } \\
\text { caixas }\end{array}$ \\
\hline ROA & $0.493 \%$ & $0.280 \%$ & $0.377 \%$ & $0.429 \%$ \\
Credit rate & $4.140 \%$ & $4.056 \%$ & $4.017 \%$ & $4.115 \%$ \\
Deposits rate & $1.457 \%$ & $1.466 \%$ & $1.574 \%$ & $1.467 \%$ \\
BP/A & $3.516 \%$ & $3.329 \%$ & $3.142 \%$ & $3.441 \%$ \\
Non-interest income / A & $0.811 \%$ & $0.761 \%$ & $0.748 \%$ & $0.794 \%$ \\
OC/A & $2.230 \%$ & $2.141 \%$ & $1.810 \%$ & $2.179 \%$ \\
P/A & $0.562 \%$ & $0.704 \%$ & $0.570 \%$ & $0.600 \%$ \\
D/A & $0.124 \%$ & $0.129 \%$ & $0.120 \%$ & $0.125 \%$ \\
Market share & $19.8 \%$ & $19.0 \%$ & $16.8 \%$ & $19.3 \%$ \\
Clients/Members & 4,670 & 4,78 & 5,243 & 4.74 \\
\hline Number of caixas & 56 & 22 & 6 & \\
In \% & $66.6 \%$ & $26.2 \%$ & $7.1 \%$ & - \\
\hline Observations in 3 year period & 168 & 66 & 18 & \\
\hline
\end{tabular}


While profitability is an indicator of overall performance, the commercial and co-operative performances are in turn related to overall profitability. Commercial performance assesses a bank's capacity to reach more clients, the ability to offer financial products that are accepted by the market and supplant the competition. Consequently, market share is a natural measure of commercial performance. In this indicator, smaller caixas have a better preformance (Table 5).

Regarding co-operative performance, we want to know if a bank achieves its co-operative goals, namely in terms of members, service to clients and members, members' participation in management, and bank's social responsibility policy. The mission defined in the statutes of caixas is to serve members, and preserving co-operative principles is very important for caixa managers. The social support for caixas as co-operatives comes from members, who are also essential for the practice of proximity banking, a comparative advantage of CA. It is through their membership base that the caixas are connected to the local economy and establish a relationship of complicity with the population they serve.

Due to the difficulty in measuring all the dimensions of co-operative performance, we focus only on the capacity to attract members, using the client to member ratio (Ureña and Úreda, 2008). The larger this ratio, the greater the orientation of caixas towards non-members. Using this indicator, we conclude from Table 5 that small caixas have a better co-operative performance.

We now turn to explaining the ROA using only the variable assets, making use of a quadratic function to allow a non-linear relationship between the variables. However, the quadratic element will be dropped when it is statistically non-significant at $10 \%$.

We can see from Figure $1^{4}$ that some small caixas have good levels of ROA. The graph shows a $U$ shaped relationship between size and ROA, which is confirmed by the regression (Table 6). Initially, the size of the caixa reduces the ROA, but size increases profitability above the threshold of approximately 300 million euros of assets. An increase of 100 million euros in assets reduces ROA by $0.28 \%$ (ignoring the squared term for simplicity). Note that only $9.7 \%$ of the variability of ROA is explained by size in the years under review, which means that there are other factors determining the caixas' profitability. We will explore the impact of other variables below, but for now we concentrate only on the impact of size. 
Figure 1. ROA (in \%) versus Assets (million euros) (2009 2011)

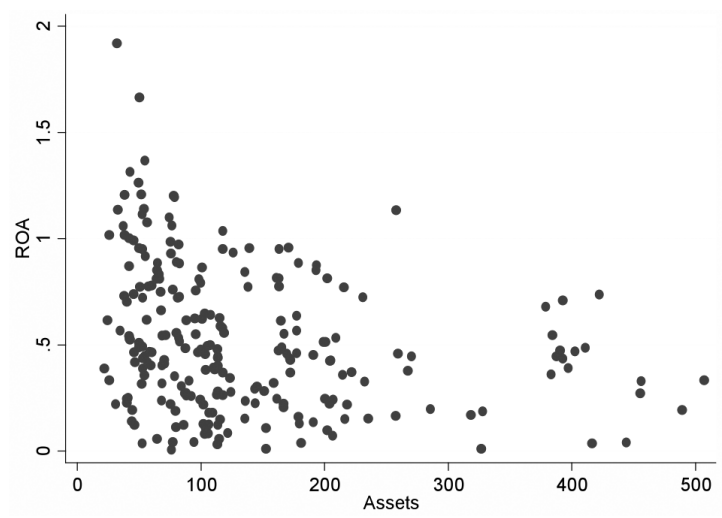

We now make a detailed analysis of the effect of size on the ratios that affect the ROA (equation 1): net-interest margin, non-interest margin (non-interest income to assets), operating costs to assets, provisions and impairments to assets, and depreciations to assets.

Using assets to explain banking product to assets (Table 6), results indicate that the smaller caixas are better at generating revenues. Next, we used assets to explain the financial margin and the noninterest margin in order to shed more light on the impact of size on banking product. Firstly, we observe that smaller caixas have a larger financial margin (Table 7). This is because smaller caixas have a larger average credit interest rate and a smaller leverage ratio (in terms of financial liabilities to financial assets). ${ }^{5}$ However, we do not observe any relation between average deposit rate and size. 


\section{Table 6. Relationship between size and ROA, Banking product, and non-interest margin}

\begin{tabular}{|c|c|c|c|}
\hline ROA & & & \\
\hline Assets & $\begin{array}{l}-0.002820^{* * *} \\
(0.000721)\end{array}$ & & \\
\hline Assets squared & $\begin{array}{l}4.5 \times 10^{-6} 6 \star \star \\
\left(1.58 \times 10^{-6}\right)\end{array}$ & $\mathrm{R}^{2}$ & 0.0970 \\
\hline Constant & $\begin{array}{l}0.766520^{* \star *} \\
(0.059402)\end{array}$ & $\mathrm{F}$ & $\begin{array}{l}15.57 \\
(p-v a l .: 0.0000)\end{array}$ \\
\hline \multicolumn{4}{|c|}{ Banking product / Assets } \\
\hline Assets & $\begin{array}{l}-0.001410^{* * *} \\
(0.000435)\end{array}$ & $\mathrm{R}^{2}$ & 0.0427 \\
\hline Constant & $\begin{array}{l}3.642746^{\star \star *} \\
(0.073114)\end{array}$ & $\mathrm{F}$ & $\begin{array}{l}10.47 \\
\text { (p-val.:0.0014) }\end{array}$ \\
\hline \multicolumn{4}{|c|}{ Non-interest Margin } \\
\hline Assets & $\begin{array}{l}-0.000229 \\
(0.000164)\end{array}$ & $\mathrm{R}^{2}$ & 0.0082 \\
\hline Constant & $\begin{array}{l}0.822111^{\star \star \star} \\
(0.027621)\end{array}$ & $\mathrm{F}$ & $\begin{array}{l}1.95 \\
\text { (p-val.:0.1644) }\end{array}$ \\
\hline Obs. & 237 & & \\
\hline
\end{tabular}

Credit interest rates may be higher in smaller caixas because their clients have higher switching costs and are less price sensitive. This is because smaller caixas tend to have a closer commercial contact with clients (i.e. there is a closer tie and more trust between clients and branch employees) and they are located in areas with less branch coverage from other banks. Indeed, small caixas have a larger market share in local banking markets and face less competition from commercial banks, enabling them to exercise their market power more effectively.

We confirm the caixas' ability to obtain revenues other than interest revenues by studying the relationship between the non-interest margin and assets (Table 6). A high non-interest margin indicates that a caixa is exploring scope economies, using its branch network to sell financial products other than credit and deposits. Nevertheless, empirical results show that size does have a statistically significant effect on the non-interest margin but there is a slight tendency for smaller caixas to have a larger noninterest margin. This is probably explained by the fact that smaller caixas started to sell insurance contracts later than larger caixas, allowing them to obtain larger revenues from a non-saturated market. 
Table 7. Relationship between size and financial margin, average credit rate and average deposit rate

\begin{tabular}{|c|c|c|c|}
\hline \multicolumn{4}{|c|}{ Financial margin / Assets } \\
\hline Assets & $\begin{array}{l}-0.001031^{* \star *} \\
(0.00031)\end{array}$ & $R^{2}$ & 0.0450 \\
\hline Constant & $\begin{array}{l}2.644482^{\star \star \star} \\
(0.052012)\end{array}$ & $\mathrm{F}$ & $\begin{array}{l}11.07 \\
(p-v a l .: 0.0010)\end{array}$ \\
\hline \multicolumn{4}{|c|}{ Average credit rate } \\
\hline Assets & $\begin{array}{l}-0.0007438^{\star} \\
(0.000414)\end{array}$ & $R^{2}$ & 0.0135 \\
\hline Constant & $\begin{array}{l}4.227775^{\star \star \star} \\
(0.069454)\end{array}$ & $\mathrm{F}$ & $\begin{array}{l}3.3 \\
\text { (p-val.:0.0737) }\end{array}$ \\
\hline \multicolumn{4}{|c|}{ Average deposit rate } \\
\hline Assets & $\begin{array}{l}0.000225 \\
(0.000283)\end{array}$ & $\mathrm{R}^{2}$ & 0.0027 \\
\hline Constant & $\begin{array}{l}1.443228^{\star \star \star} \\
(0.047629)\end{array}$ & $\mathrm{F}$ & $\begin{array}{l}0.63 \\
(p-v a l .: 0.4289)\end{array}$ \\
\hline \multicolumn{4}{|c|}{ Financial liabilities / Financial assets } \\
\hline Assets & $\begin{array}{l}0.0003167^{\star \star} \\
(0.0001212)\end{array}$ & $R^{2}$ & 0.0478 \\
\hline Assets squared & $\begin{array}{l}4.96 \times 10^{-7} * \\
\left(2.65 \times 10^{-7}\right)\end{array}$ & $\mathrm{F}$ & $\begin{array}{l}5.87 \\
(p-v a l .: 0.0033)\end{array}$ \\
\hline Constant & $\begin{array}{l}0.9115863^{\star \star \star} \\
(0.0099777)\end{array}$ & & \\
\hline Obs. & 237 & & \\
\hline
\end{tabular}

The effect of size has been studied in the literature largely in terms of costs. We now observe the regressions related to costs in an attempt to determine the existence of scale economies. Firstly, results show that larger caixas have smaller operating costs, confirming the existence of scale economies (Table 8).

Depreciations are also an important cost item, and regressions results reveal a significant inverted U-shaped relationship between size and depreciations (Table 8). Initially, the size leads to larger depreciations, but gains come from scale after approximately 250 million euros of assets. Larger caixas are able to dilute depreciations through their high business volumes. However, small caixas have a lower ratio of depreciations than medium-sized caixas essentially because they have rented facilities or own relatively small buildings. 
Provisions and impairments are a very important cost component for a credit institution. This ratio for larger banks tends to be smaller even though the effect is not statistically significant ( $p$-value of 0.107 ) - Table 8. This is probably an indicator that larger caixas benefit from the diversification of risk that results from having a larger credit portfolio.

\section{Table 8. Relationship between size and operating costs, provisions and depreciations}

\begin{tabular}{|c|c|c|c|}
\hline \multicolumn{4}{|c|}{ Operating costs / Assets } \\
\hline Assets & $\begin{array}{l}-0.0008669^{\star \star \star} \\
(0.000264)\end{array}$ & $\mathrm{R}^{2}$ & 0.0439 \\
\hline Constant & $\begin{array}{l}2.280459^{* \star *} \\
(0.04429)\end{array}$ & $\mathrm{F}$ & $\begin{array}{l}10.78 \\
\text { (p-val.: 0.0012) }\end{array}$ \\
\hline \multicolumn{4}{|c|}{ Provisions / Assets } \\
\hline Assets & $\begin{array}{l}-0.0018052 \\
(0.0011145)\end{array}$ & $\mathrm{R}^{2}$ & 0.0110 \\
\hline Constant & $\begin{array}{l}3.174409^{\star \star \star} \\
(0.1869631)\end{array}$ & $\mathrm{F}$ & $\begin{array}{l}2.62 \\
(p-v a l .: 0.1066)\end{array}$ \\
\hline \multicolumn{4}{|c|}{ Depreciations / Assets } \\
\hline Assets & $\begin{array}{l}0.0002466^{\star \star} \\
(0.0001091)\end{array}$ & $\mathrm{R}^{2}$ & 0.0218 \\
\hline Assets squared & $\begin{array}{l}-4.96 \times 10^{-7} \text { ** } \\
\left(2.39 \times 10^{-7}\right)\end{array}$ & $\mathrm{F}$ & $\begin{array}{l}2.61 \\
\text { (p-val.: } 0.0760)\end{array}$ \\
\hline Constant & $\begin{array}{l}0.1056964^{\star \star \star} \\
(0.0089786)\end{array}$ & & \\
\hline Obs. & 237 & & \\
\hline
\end{tabular}

Turning now to the commercial efficiency, some caixas have a very large market penetration and capture more than $50 \%$ of the market. However, we do not find a statistically significant relationship between size and market share (Table 9).

It is also important to study whether size has a negative effect on the preservation of co-operative principles. We therefore examine the relationship between the number of customers (be they members or not) in a caixa and the client to member ratio. The regression indicates that caixas with more customers have higher client to member ratios, with this relationship inverting for very large caixas (more than 55,000 clients) - Table 9. In other words, the more customers a caixa has, the smaller the percentage of members. With an average client to member ratio of 4.7 , an increase of 15,000 clients (which is equivalent to a standard deviation of this variable) implies an increase in that ratio of 1 (ignoring the non-linear effect). As for profitability (see above), medium-sized caixas are the worst in terms of associative efficiency. 
We can thus conclude that the associative relationship is not harmed in the large caixas. This is probably because some very large caixas focus on membership quality and quantity and have commercial activities which aim to capture new members, and promote initiatives for the mass participation of members in general meetings. It seems then that the management's commitment to the relationship with members is a key to guaranteeing high membership levels.

\section{Table 9. Relationship between size and market share and members}

\begin{tabular}{|c|c|c|c|}
\hline \multicolumn{4}{|l|}{ Market share } \\
\hline Assets & $\begin{array}{l}-0.0004206 \\
(0.0002848)\end{array}$ & $\mathrm{R}^{2}$ & 0.0110 \\
\hline Assets squared & $\begin{array}{l}4.65 \times 10^{-7} \\
\left(6.23 \times 10^{-7}\right)\end{array}$ & $\mathrm{F}$ & $\begin{array}{l}1.31 \\
(p-v a l .: 0.2730)\end{array}$ \\
\hline Constant & $\begin{array}{l}0.2309918^{\star \star \star} \\
(0.0234442)\end{array}$ & & \\
\hline Obs. & 237 & & \\
\hline \multicolumn{4}{|c|}{ Clients / Members } \\
\hline Clients & $\begin{array}{l}0.0000699^{\star * \star} \\
(0.0000258)\end{array}$ & $R^{2}$ & 0.0470 \\
\hline Clients squared & $\begin{array}{l}-7.52 \times 10^{-10 *} \\
\left(3.86 \times 10^{-10}\right)\end{array}$ & $\mathrm{F}$ & $\begin{array}{l}5.72 \\
(p-v a l .: 0.0038)\end{array}$ \\
\hline Constant & $\begin{array}{l}3.790709^{\star * *} \\
(0.3228555)\end{array}$ & & \\
\hline Obs. & 235 & & \\
\hline
\end{tabular}

\subsection{Multivariate analysis}

So far we considered the size of a caixa as the only explanatory variable of profitability. However, other determinants should be considered to provide a better explanation of profitability. The literature on co-operative banking has already highlighted several determinants of efficiency, which were grouped by Worthington (2009) as follows: the relevance of the mutual form versus the corporation form; regulation, organizational and legal aspects; number of branches; and mergers. In the case of CA caixas, some of these variables are not relevant since they all have the co-operative form and are subject to the same regulation and legal frameworks.

We considered the following variables to explain profitability: market share, solvency ratio (capital/assets), average wage (staff costs/number of employees), ratio of credit provisions to assets, ratio 
of number of branches to assets, labour productivity (banking product per worker), ratio of customers to members, and município purchasing power. ${ }^{6}$

The rationale for including each of the mentioned variables is as follows. Firstly, the caixas with larger market share are expected to exercise greater market power on their customers and thus charge higher lending rates and pay lower deposit rates, which contributes to a higher return. Even though clients are free to choose other banks offering better interest rates, the banking system is Portugal is not very competitive and has characteristics of an oligopoly. Moreover, our argument is more valid for the caixas that operate in areas where there is little offer of banking services by other banks. Amel and Froeb (1991) for a sample of banking firms in Texas conclude that market share is not relevant for profitability.

As for the solvency ratio, it is anticipated that the caixas with less solvency miss lucrative opportunities to grant credit due to insufficiency of capital and have less time and flexibility to deal with unexpected losses (Athanasoglou et al., 2008). In addition, these banks have more difficulty in attracting deposits because they inspire less confidence. Along this line of reasoning, several authors, including Abreu and Mendes (2002), Staikouras and Wood (2004), Goddard et al. (2004) and Athanasoglou et al (2008), conclude that banks with higher levels of equity relative to assets have better profitability. They argue that better capitalized banks have less probability of bankruptcy and thus lower funding costs. Additionally, higher equity to assets usually implies less external funding and thus higher profitability (Pasiouras and Kosmidou, 2007).

The quality of human capital may be better in caixas with higher average wages (this is a quality effect of higher spending, Athanasoglou et al, 2008), but on the other hand they may be less efficient in containing wage costs. Hence, only the empirical analysis will clearly indicate what to expect for this variable. However, other studies stress that operational efficiency in terms of low operating costs (much of which is wages) is an important and positive determinant of banks' profitability (Athanasoglou et al, 2008; Goddard et al, 2009).

A labour productivity indicator was also introduced, as in Athanasoglou et al., (2008). Since the human factor is crucial in the banking business, the caixas with higher labour productivity are also expected to have higher ROA.

We also considered the ratio of provisions for loan losses to assets, which has a direct negative impact on ROA and is an indicator of the quality of a caixa's credit management. Molyneux and Thornton (1992) and Staikouras and Wood (2003), among others, find a negative relationship between loan risk and profitability. A higher proportion of high risk loans leads to larger amounts of unpaid credit thus reducing banks' profitability. 
Similarly, the ratio of the number of branches to assets was introduced since caixas with many branches may be less profitable due to their additional costs. On the other hand, caixas with more branches are better able to perform their intermediation activity and can obtain a larger return. These conflicting hypotheses have already been identified by Fried et al. (1993), for instance.

As above, the ratio of clients to members was used as a proxy of the level of connection to co-operative principles. If a high percentage of the caixa's customers are members (in which case the variable of clients to member will be smaller), the management is expected to be monitored better by stakeholders and there will be more proximity between management and beneficiaries of the banking services. Additionally, a high percentage of members also means that customer loyalty is higher, which favours the caixa's profitability. Finally, because members share some kind of common bond, the social pressure to repay the loan is greater and the bank has better access to inside information that reduces adverse selection and moral hazard by clients, implying more profitability (Esho, 2001). However, it is expected that caixas closer to the co-operative principles of serving small clients, who originate low return operations, and with personal and close contact with clients will have a larger number of workers and thus lower labour productivity and return (Ureña and Úbeda, 2008). This means that the overall impact of the clients to members variable is uncertain a priori.

Finally, we introduced the average purchasing power of the municipios served by each caixa (in 2009 and obtained from INE - Portuguese Institute of Statistics) in order to capture the level of development of the local economy, which may affect the profitability of the caixas (Dietrich and Wanzenried, 2011).

Results confirm a U-shaped relationship between a caixa's size and profitability (Table 10 - OLS). The ROA decreases with size up to 317 million euro of assets, but thereafter it increases. Dietrich and Wanzenried (2011) also found a U-shaped relationship between size and return for Swiss banks.

We now turn to the impact of other explanatory variables. Market share has a negative impact on profitability (with a p-value of 0.102 ), indicating that the caixas with greater market power are more insulated from competition and so have less incentive to be efficient. Similarly, the average wage has a negative effect on ROA, confirming the hypothesis that caixas that pay higher wages are run less efficiently and are not necessarily hiring better workers. However, workers' productivity is an important factor to explain assets' return. A further confirmation of the importance of human capital is that caixas that manage credit risk less efficiently also have lower ROA. Solvability is not statistically important for profitability, as was the case for Swiss banks before the 2007-09 crisis (Dietrich and Wanzenried, 2011). It is important to recognize that better solvency implies a higher return mainly because it reduces the cost of external financing. However, this advantage is less relevant for the caixas, because they finance themselves with deposits rather than using bonds or the IMM. Moreover, when they do need financing, they use the CC. 
Additionally, the caixas with more branches to assets also have a higher ROA (with a p-value of 0.083), possibly because they are closer to the proximity banking typical of co-operative banking. The caixas with proportionally more members are also more profitable, which draws attention to the fact that caixas should give full consideration to their co-operative roots. Finally, it is curious that the purchasing power of the municipio does not seem to affect profitability.

We now estimate the regression considering fixed effects that capture caixas' characteristics constant over time. Among other things, these effects may include organization and management culture, competitive position on the market, and local economy characteristics. Empirical results indicate that both size and the proportion of members are no longer important (Table 10, FE-III). A possible interpretation of this result is that the specific characteristics of caixas that make them more efficient are correlated with size, so size becomes non-significant when these characteristics are taken into account. In other words, it is the unobserved specific characteristics and not size that makes smaller and larger caixas more profitable than medium sized caixas.

In order to understand why size became less relevant to the return, it is necessary to take into account that bank size may increase labour productivity and improve credit risk management. This means these elements capture part of the size effect. We therefore removed these two variables to analyse this hypothesis, with the result that size has a positive effect on return (Table 10, FE-I). When we re-introduce labour productivity, we observe that the effect of size is still present (Table 10, FE-II). It is only after introducing the provisions to credit ratio that the effect of size becomes non-significant (Table 10, FE-I). ${ }^{7}$ This seems to indicate that, with multiple explanatory variables and fixed effects, the impact of size on return operates through the improvement of credit risk management. 
Table 10. Multivariate analysis

\begin{tabular}{|c|c|c|c|c|}
\hline Variables & OLS & FE-I & FE-II & FE-III \\
\hline Assets & $\begin{array}{l}-0.002548^{\star \star *} \\
(0.0006541)\end{array}$ & $\begin{array}{l}0.016625^{\star} \\
(0.008484)\end{array}$ & $\begin{array}{c}0.014324^{*} \\
(0.0077205)\end{array}$ & $\begin{array}{c}0.009063 \\
(0.007651)\end{array}$ \\
\hline Assets squared & $\begin{array}{c}4.02 \times 10^{-6 * \star *} \\
(1.40 \mathrm{E}-05)\end{array}$ & $\begin{array}{l}-0.000015 \\
(0.000011)\end{array}$ & $\begin{array}{l}-0.000015 \\
(0.000010)\end{array}$ & $\begin{array}{l}-0.000012 \\
(0.000010)\end{array}$ \\
\hline Market Share & $\begin{array}{l}-.2534207 \\
(.1545166)\end{array}$ & $\begin{array}{l}-0.004912 \\
(0.725127)\end{array}$ & $\begin{array}{l}-0.204353 \\
(0.659857)\end{array}$ & $\begin{array}{l}-0.168825 \\
(0.639136)\end{array}$ \\
\hline Solvability & $\begin{array}{l}0.3276035 \\
(0.409212)\end{array}$ & $\begin{array}{c}9.92393^{\star *} \\
(4.239301)\end{array}$ & $\begin{array}{c}5.963613 \\
(3.916388)\end{array}$ & $\begin{array}{c}3.392174 \\
(3.875224)\end{array}$ \\
\hline Average wage & $\begin{array}{c}-9.34 \times 10^{-6 * *} \\
(4.10 \mathrm{e}-06)\end{array}$ & $\begin{array}{l}0.000019^{\star *} \\
\left(7.31 \times 10^{-6}\right)\end{array}$ & $\begin{array}{l}7.89 \times 10^{-7} \\
\left(7.40 \times 10^{-6}\right)\end{array}$ & $\begin{array}{l}-2.42 \times 10^{-7} \\
\left(7.17 \times 10^{-6}\right)\end{array}$ \\
\hline Branches/Assets & $\begin{array}{c}1782486^{*} \\
(1023037)\end{array}$ & $\begin{array}{l}-3641243 \\
(6245426)\end{array}$ & $\begin{array}{l}-1198712 \\
(5691706)\end{array}$ & $\begin{array}{c}1895655 \\
(5594518)\end{array}$ \\
\hline Clients/Members & $\begin{array}{c}-.0199526^{\star \star} \\
(.0100368)\end{array}$ & $\begin{array}{l}0.0106075 \\
(0.022173)\end{array}$ & $\begin{array}{l}0.0429497^{\star \star} \\
(0.0209586)\end{array}$ & $\begin{array}{c}0.0057997 \\
(0.0233202)\end{array}$ \\
\hline Labour Productivity & $\begin{array}{l}6.13 \times 10^{-6} \times * \star \\
\left(7.99 \times 10^{-7}\right)\end{array}$ & D乎 & $\begin{array}{l}8.60 \times 10^{-6 * \star * \star} \\
\left(1.53 \times 10^{-6}\right)\end{array}$ & $\begin{array}{l}9.50 \times 10^{-6 * \star \star \star} \\
\left(1.51 \times 10^{-6}\right)\end{array}$ \\
\hline Provisions/Credit & $\begin{array}{l}-.0333144^{\star \star \star} \\
(0.0109475)\end{array}$ & - & - & $\begin{array}{c}-0.109350^{\star \star \star} \\
(0.0337984)\end{array}$ \\
\hline Munícipio purchasing power ${ }^{1}$ & $\begin{array}{l}-0.0015212 \\
(0.0013067)\end{array}$ & - & - & - \\
\hline Obs & 235 & 235 & 235 & 235 \\
\hline $\begin{array}{l}F \\
\text { (p-val.) }\end{array}$ & $\begin{array}{c}13.29 \\
(0.0000)\end{array}$ & $\begin{array}{c}3.66 \\
(0.0011)\end{array}$ & $\begin{array}{c}7.81 \\
(0.0000)\end{array}$ & $\begin{array}{c}8.56 \\
(0.0000)\end{array}$ \\
\hline $\mathrm{R}^{2}$ & $\begin{array}{c}\text { R2 ajust: } \\
0.3446\end{array}$ & $\begin{array}{c}\text { R2 within: } \\
0.1511\end{array}$ & $\begin{array}{c}\text { R2 within: } \\
0.3040\end{array}$ & $\begin{array}{c}\text { R2 within: } \\
0.3518\end{array}$ \\
\hline F test of all FE equal to 0 & - & $\begin{array}{c}2.25 \\
\text { (p-val.: } 0.0000)\end{array}$ & $\begin{array}{c}2.15 \\
\text { (p-val.: } 0.0000)\end{array}$ & $\begin{array}{c}2.26 \\
\text { (p-val.: } 0.0000)\end{array}$ \\
\hline
\end{tabular}

Note: 1 - Because the município purchasing power refers to 2009 and is fixed during the sample, it is dropped when we use fixed effects. 


\section{6.- Conclusion}

The banking practice of co-operative banks and CA in particular relies on proximity with the populations and a large network of branches mainly in rural areas. Over the years, the CA has evolved considerably and today it is a modern bank able to compete in the open market with other commercial banks, and has shown a strong resilience during the recent crisis. The CA strategy has favoured mergers between caixas with the goal of creating stronger local banks. This paper therefore aims to study whether larger caixas are more profitable.

The regression with a single explanatory variable reveals that ROA is affected by the size of the caixa, and it has a $U$ shaped relationship: size initially decreases ROA, but when the scale exceeds 300 million euros of assets, size has a favourable effect on ROA. This statistical evidence shows that small and large caixas have the best returns, leaving the medium-sized caixas "stuck in the middle".

We then made a detailed analysis of the effect of size on return. Regarding income variables, we found that small caixas generate a larger financial margin because they charge higher credit rates and have smaller leverage i.e. indebtedness levels. The non-interest margin does not seem to be related with size.

In terms of operating costs, larger caixas take advantage of scale economies. Depreciations have an inverted $U$-shaped relationship with size; the large and small caixas have the best performance, while the medium-sized caixas have the worst performance. Indeed, it is the better performance in terms of operating costs and depreciations of the large caixas that explains why they have a higher ROA than the medium-sized caixas. Provisions and impairments are not affected in a statistically significant way by the size of the caixa.

Our evidence indicates that small caixas follow a niche strategy that proves profitable namely in terms of generating larger financial margins. At the opposite extreme, we have larger caixas that benefit from their size as it allows them to explore scale economies in operating costs and depreciations. Medium-sized caixas are the least profitable because they are not small enough to offer a customized service that creates loyal clients and generates high financial margins in the same way as small caixas; but they are not large enough to explore the scale economies of large caixas.

As for the associative component, the statistical evidence shows that the larger the number of customers, the smaller the member to customer ratio, and that this relationship inverts for very large caixas. Commercial efficiency is not affected by the size of the local bank. 
After introducing other variables that affect profitability into the equation, the analysis confirms the $U$ shaped relationship between size and return. Further, as it is the caixas with more members (in relation of customers) that have better return, this underlines the importance caixas should give to their cooperative root ensuring customer loyalty and supporting business.

However, considering the time-invariant characteristics of each caixa (fixed effects), the effect of size on profitability becomes insignificant. This suggests that the initial higher profitability of small and larger caixas in relation to medium-size caixas was explained by their specific time-invariant characteristics. Our results also suggest that size has an indirect effect on return through credit risk: larger caixas have a better credit risk management. Finally, with fixed effects, co-operative membership does not affect return anymore.

Our work not only supports the formation of larger local banks in co-operative groups, but also underlines the importance of good human resources management for profitability. Large local banks should be formed with care in order not to alienate members and undermine the co-operative principles of institutions.

\section{References}

ABREU, M. \& MENDES, V. (2002): "Commercial Bank Interest Margins and Profitability: Evidence from E.U. Countries", Working Paper Series, Porto.

ALTUNBAS, Y., GARDENER, E.P.M., MOLYNEUX, P. \& MOORE, B. (2001): "Efficiency in European banking", European Economic Review, 45, 1931-1955.

AMEL, D. \& FROEB, L. (1991): "Do firms differ much?", Journal of Industrial Economics, 39, 323-9.

ATHANASOGLOU, P.P., BRISSIMIS, S.N. \& DELLIS, M. D. (2008): "Bank-specific, industry-specific and macroeconomic determinants of bank profitability", Journal of International Financial Markets, Institutions and Money, 18(2), 121-136.

BALLARIN, E. (1985): Estratégias Competitivas para la Banca, Ariel, Barcelona

BARRADAS, R., LAGOA, S. \& LEAO, E. (2011): "The Non-For-Profit Bank in Portugal: Specificities social role and evolution", Review of Solidarity Economy, 4, 58-97.

BATISTA, A. (2010): "As Fusões no Crédito Agrícola", Informação Técnica Crédito Agrícola, Departamento de Fiscalização e Orientação da Caixa Central Crédito Agrícola. 
BELMONTE, L.J. \& CORTÉS, F.J. (2010): "La concentración del sector de cooperativas de crédito en España", CIRIEC-España, Revista de Economía Pública, Social y Cooperativa, 68, 223-246.

BERGER, A., HANWECK, D. \& HUMPHREY, D. (1987): "Competitive viability in banking: Scale, scope, and product mix economies", Journal of Monetary Economics, 20 (3), 501-520.

BERGER, A., DEYOUNG, R., GENAY, H. \& UDELL, G.F. (2001): "Globalization of Financial Institutions Evidence from cross-border banking performance", FRB Chicago Working Paper No. 1999-25, March 21.

BOYD, J. \& RUNKLE, D. (1993): "Size and performance of banking firms: testing the predictions of theory", Journal of Monetary Economics, 31, 47-67.

BROWN, R., BROWN, R. \& O'CONNOR, I. (1999): "Efficiency, bond of association and exit patterns in credit unions: Australian evidence", Annals of Public and Cooperative Economics, 70(1), 5-23.

CA CONSULT (2011): "Cem anos de Crédito Agrícola comemoração do centenário", Crédito Agrícola.

CABO, P. (2003): "As fusões o Sistema Integrado de Crédito Agrícola Mútuo", Master Thesis in Entreprise and Industrial Economics, University of Minho.

CABO, P. \& REBELO, J. (2005): "Why do Agricultural Credit Cooperatives Merge? The Portuguese Experience", Annals of Public and Cooperative Economics, 76 (3), 491-516.

COELHO, M. (2011): "Avaliação dos efeitos da crise financeira nas actividades das Caixas de Crédito Agrícola", Master Thesis in Accounting, Taxes and Finance, Technical University of Lisbon.

DIETRICH, A. \& WANZENRIED, G. (2011): "Determinants of bank profitability before and during the crisis: Evidence from Switzerland", Journal of International Financial Markets, Institutions \& Money 21, 307-327.

DRAKE, L. \& WEYMAN-JONES, T.G. (1992): "Technical and scale efficiency in UK building societies", Applied Financial Economics, 2(1), 1-9.

EACB (2010): "European Co-operative Banks in the Financial and Economic Turmoil: First Assessments", Research Paper, EACB.

ENCINAS, B. (2010): "Las cajas rurales frente a la crisis. Comportamiento de los diferentes modelos de negocio en función de la conformación de su eficiencia operativa", CIRIEC-España, Revista de Economía Pública, Social y Cooperativa, 68, 81-110.

ESHO, N. (2001): "The determinants of cost efficiency in cooperative financial institutions: Australian evidence", Journal of Banking and Finance, 25, 941-964.

FAJARDO, G. (2011): "How viable are spanish credit cooperatives after recent bank capitalization and restructuring regulations?", CIRIEC-España, Revista de Economía Pública, Social y Cooperativa, $73,151-170$. 
FERREIRO, M.F., LAGOA, S. \& PINA, L. (2012): "Cooperative Financial Institutions and Regional and Rural Development: The Portuguese Case", Presented at the Conference 'Cooperative Responses to Global Challenges', Berlin.

FIELD, K. (1990): "Production efficiency of British building societies", Applied Economics, 22, 415-426.

FONTEYNE, W. (2007): "Cooperative Banks in Europe - Policy Issues", IMF Working Paper, 07/159, July.

FRIED, H.O., LOVELL, C.A.K. \& VANDEN E.P. (1993): "Evaluating the performance of US credit unions", Journal of Banking and Finance, 17(2-3), 251-265.

GIJSELINCKX, C. \& DEVELTERE, P. (2008): "The co-operative trilemma. Co-operatives between market, state and civil society", Working paper on Social and Co-operative Entrepreneurship, WP-SCE 08.01 .

GODDARD, J., MCKILLOP, D. \& WILSON, J.O.S. (2008): "What drives the performance of cooperative financial institutions? Evidence for US credit unions?", Applied Financial Economics 18, 879-893.

GODDARD, J., MOLYNEUX, P. \& WILSON, J. (2004): "The profitability of European Banks: a crosssectional and dynamic panel analysis", Manchester School, 72 (3), 363-381.

GODDARD, J., LIU, H., MOLYNEUX, P. \& WILSON, J.O.S. (2010): “Do bank profits converge?”, European Financial Management, Nov., published online.

GROENEVELD, J.M. \& SJAUW-KOEN-FA, A. (2009): "Co-operative banks in the new financial system", Rabobank Group Report, October.

GROENEVELD, H. (2014): "Features, facts and figures of European cooperative banking groups over recent business cycles", Journal of Entrepreneurial and Organizational Diversity, 3 (1), 11-33.

GUIDER, H. \& ROUX, M. (2009) : La Banque Coopérative en Europe - Stratégies et défis, Revue Banque Éditions, Paris.

HESSE, H. \& CIHAK, M. (2007): "Co-operative Banks and Financial Stability", IMF Working Paper 07/02, IMF, January.

JONES, G. (1988): "Transaccion Cost Analysis of Strategy - Structure Choice", Strategic Management Journal, 9 (2), 159-172.

LANG, G. \& WELZEL, P. (1996): "Efficiency and technical progress in banking: Empirical results for a panel of German cooperative banks", Journal of Banking and Finance, 20, 1003-1023.

LIMA, D. (2012): "Forecasting insolvencies of Portuguese co-operative banks", Third Prize in the First EACB Award Young Researchers on Co-operative Banks 2012, 19 pages.

KUIJPERS, A. (2011): Banking Regulation, Rabobank, Utrecht.

MCKILLOP, D.G., GLASS, C.J. \& FERGUSON, C. (2002): "Investigating the cost performance of UK credit unions using radial and non-radial efficiency measures", Journal of Banking and Finance, 26, $1563-1591$. 
MICCO, A., PANIZZA, U. \& YANEZ, M. (2007): "Bank ownership and performance. Does politics matter?", Journal of Banking and Finance, 31 (1), 219-241.

MOLYNEUX, P. \& THORNTON, J. (1992): "Determinants of European Bank Profitability: A Note", Journal of Banking and Finance 16 (6), 1173-1178.

MOLYNEUX, P., ALTUNBAS, Y. \& GARDENER, E.P.M. (1996): Efficiency in European Banking, Wiley, Chichester, UK.

PALOMO, R.J. (2008): "Co-operative banking groups in Europe: Comparative analysis of the structure and activity", CIRIEC-España, Revista de Economía Pública, Social y Cooperativa, 62, 87-119.

PASIOURAS, F. \& KOSMIDOU, K. (2007): "Factors influencing the profitability of domestic and foreign commercial banks in the European Union", Research in International Business and Finance, 21 (2), 222-237.

PORTER, M. (1980): Competitive Strategy - Techniques for analysing industries and competitors, The Free Press, New York.

RALSTON, D., WRIGHT, A. \& GARDEN, K. (2001): "Can mergers ensure the survival of credit unions in the third millennium?", Journal of Banking and Finance, 25, 2277-2304.

SANCHIS, J.R. (2003): "Análisis estratégico de las cooperativas de crédito. Estudio empírico aplicado a las cajas rurales de la Comunidad Valenciana", ICE, 805, Marzo.

SANTOS, D. (2012): "Do Mutualismo ao Mercado, a Banca Mutualista em Portugal. Estudo de caso: Credito Agrícola", Master Thesis in Sociology, University Nova of Lisbon.

STAIKOURAS, C. \& WOOD, G. (2004): "The determinants of European bank profitability", International Business and Economics Research Journal, 3 (6), 57-68.

WORTHINGTON, A.C. (1998): "Testing the association between production and financial performance: Evidence from a not-for-profit co-operative setting", Annals of Public and Co-operative Economics, 69(1), 67-83.

WORTHINGTON, A.C. (1999): "Measuring technical efficiency in Australian credit unions", The Manchester School, 67 (2), 231-248.

WORTHINGTON, A.C. (2001): "Efficiency in pre-merger and post-merger non-bank financial institutions", Managerial and Decision Economics, 22, 439-452.

WORTHINGTON, A.C. (2004): "Determinants of merger and acquisition activity in Australian cooperative deposit-taking institutions", Journal of Business Research, 57, 47-57.

WORTHINGTON, A.C. (2009): "Frontier Efficiency Measurement in Deposit-taking Financial Mutuals: A review of Techniques, Application, and Future Research Directions", Griffith Business School Discussion Papers Finance, No. 2009-11. 


\section{Appendix}

\section{Table A1 - Descriptive statistics}

\begin{tabular}{|l|ccccc|}
\hline Variables & Obs & Mean & Std. Dev. & Min & Max \\
\hline ROA (\%) & 235 & 0.5168 & 0.3365 & 0.0038 & 1.9211 \\
Financial margin /Assets (A) (\%) & 235 & 2.5090 & 0.4921 & 0.7277 & 3.8850 \\
Non-interest margin /A (\%) & 235 & 0.7922 & 0.2568 & 0.2716 & 1.7932 \\
Average credit rate (\%) & 235 & 4.1202 & 0.6421 & 1.0012 & 6.0656 \\
Average deposit rate (\%) & 235 & 1.4681 & 0.4368 & 0.2175 & 2.5444 \\
Financial liabilities / Financial assets & 235 & 0.9389 & 0.0534 & 0.4461 & 1.0507 \\
Banking product /A (\%) & 235 & 3.4584 & 0.6900 & 1.1465 & 5.4721 \\
Operating costs / A (\%) & 235 & 2.1644 & 0.4199 & 0.7501 & 3.6068 \\
Total provisions / A (\%) & 235 & 0.5409 & 0.4193 & -0.8020 & 1.6783 \\
Credit Provisions / A (\%) & 235 & 2.9494 & 1.7334 & 0.3296 & 11.6105 \\
Depreciations / A (\%) & 235 & 0.1242 & 0.0485 & 0.0249 & 0.2446 \\
Market share & 235 & 0.1969 & 0.1268 & 0.0103 & 0.5567 \\
Solvability & 235 & 0.1060 & 0.04978 & -0.0820 & 0.2462 \\
Average wage (euros) & 235 & 39074.17 & 5809.28 & 12098.96 & 60805.88 \\
Branches/Assets (no. Branches / & 235 & $6.17 \times 10^{-8}$ & $2.16 \times 10^{-8}$ & $1.21 \times 10^{-8}$ & $1.42 \times 10^{-7}$ \\
$\quad$ assets in euros) & 235 & 4.7293 & 1.8889 & 1.5579 & 13.8838 \\
Clients/Members & 235 & & & \\
Labour Productivity (banking product & 235 & 114783.1 & 29778.74 & 33325.09 & 289460.5 \\
in euros / no. workers) & & & & & \\
Freguesia purchasing power & 235 & 76.5667 & 15.0587 & 53.5037 & 126.7983 \\
(100 is the national average) & & & & & \\
\hline
\end{tabular}

